\title{
INVENTING THE COMMUNIST PARTY OF LITHUANIA AS A LABOUR MOVEMENT. NARRATIVES IN SOVIET HISTORIOGRAPHY
}

\author{
Ugnè Marija Andrijauskaité \\ (Vytautas Magnus University)
}

\begin{abstract}
This study analyses and shows how the history of the Communist Party of Lithuania (Lietuvos komunistu partija, LKP) was constructed as the history of an organised labour movement in Soviet historiography. Most studies on Lithuanian workers and labour unions written between 1960 and 1988 searched for connections between the LKP and the labour movement, analysed the impact of the LKP on the workers and unions, and sometimes used the terms 'workers' or 'labouring men' as synonyms for members of the LKP. According to Soviet Lithuanian historians, labour unions, strikes, workers, and the whole organised labour movement that sympathised with Moscow, helped to gain influence among the citizens of Lithuania prior to the occupation in 1940.

Because the labour history of Soviet Lithuania was tied to the history of the Lithuanian Communist Party, it is still hard to draw a line between the history of the workers and the history of the LKP, since the studies on workers, the labour movement and the history of the LKP written during Soviet times are treated as a product of the ideology. It is argued that Soviet Lithuanian labour history must be properly reviewed in order to reevaluate its relationship with contemporary historiography and today's perception of the labour movement itself.
\end{abstract}

KEYWORDS: Lithuanian historiography; labour history; Soviet historiography; Lithuania 1918-1940; Lithuanian Communist Party.

\section{Introduction}

The famous historian Eric Hobsbawm wrote that it is 'practically impossible to find any labour movements of whatever kind in which socialists or people formed in the socialist movements did not play a significant part. This symbiosis of labour movement and socialism was evidently not fortuitous. Both sides derived advantages from it, except for the systems of "really existing socialism" which abolished labour movements in the name of parties claiming to represent the 
working class and in the name of socialism. ${ }^{1}$ Lithuania was no exception. The labour movement was born here in the late 19th century, when it was part of the Russian Empire, and flourished in the light of the revolution of 1905. Soon afterwards, when the Bolsheviks came to power in Russia, Lithuania declared its independence. The new Communist Party of Lithuania followed the lead of the Russian Communist Party, and carried on its activities underground. Even though the Bolsheviks came to power in the name of the proletariat, they abolished the labour movement as we know it, and banished workers' organisations which were not controlled by the Party (and later by the state). That is why, according to Hobsbawm 'it is possible to write the history of the working class in the communist world and even a history of labour conflicts, but not the history of labour movements. ${ }^{2}$ However, since Lithuania was not a part of the communist world until 1940, an attempt can and should be made to write the history of the Lithuanian labour movement. This short study is about the history and the writing of labour history in Lithuania from 1945 to 1990. It also provides some brief but valuable information about Soviet Lithuanian historiography.

The impact of the Soviet occupation is still visible in Lithuanian society, and the same might be said about Soviet historiography: even though there were (and still are) discussions about its value and/or being worthless, the dominant view in historical studies of Soviet Lithuania can be described by a quote from the back of the book 'Soviet Lithuanian Historiography': ${ }^{3}$

'Soviet relics [of historiography] must be evaluated consciously and critically: the wheat should be separated from the chaff, and it should be decided what must be renounced and what must be invoked and continued. Only after the reckoning with the Soviet era will we be able to look for new forms of historiography with a clean conscience. ${ }^{4}$

Therefore, quite often, instead of dealing with Soviet historiography as a whole historical tradition, it is chosen to recycle Soviet historiography: to put studies with some empirical value into a pile of books which can be (re)used, and to throw the rest of the stud-

${ }^{1}$ E. Hobsbawm, How to Change the World. Reflections on Marx and Marxism (London, 2011), p. 403.

2 Ibid., p. 410.

${ }^{3}$ Lietuvos sovietine istoriografija, ed. A. Bumblauskas, N. Šepetys (Vilnius, 1999).

${ }^{4}$ Ibid., the back of the book. 
ies into the rubbish heap of history. It is doubtful that 'the dustbin of history', as any other landfill, has no value to researchers. The greatest discoveries about everyday life might be made by archaeologists studying the contents of ancient scrap heaps; so maybe the same can be done by historians doing a similar kind of archaeology?

There are only a few articles on the labour movement in Lithuania between 1918 and 1940 written after 1990, but numerous studies were published between 1945 and 1990. Occasionally, it is chosen to ignore studies of workers written before 1990 (it would probably be incorrect to label them as 'labour history') and treat them as chaff because of their poor empirical and/or historical value. However, even though Soviet Lithuanian studies of the working class might not be useful for empirical data, they can provide us with knowledge of how such studies were written, and what impact they have had on today's perception of Lithuanian labour history among historians and Lithuanian society. Only about 8 or 9 per cent of the labour force in Lithuania is unionised, and labour unions are often seen as a 'Soviet relic'. It is possible that analysing 'the dustbin of history' can change the perception of both Soviet historical studies of the labour movement of Lithuania and the image of today's labour unions in Lithuania.

The first steps to (re)evaluate Soviet Lithuanian history have already been taken, most notably by Aurimas Švedas in his study Matricos nelaisveje: sovietmečio lietuviu istoriogafija (1944-1985 m.) (In the Captivity of the Matrix: Soviet Lithuanian historiography (1944-1985)). However, the main subject of that book is the historians themselves. It is clear that a deep analysis of all 'rejected' Soviet historiography would take much more time and would be of greater volume, which is why this article looks at only a part of it, the studies of the Lithuanian working class and labour movement conducted between 1960 and 1988. Earlier studies (especially those written during the Stalinist era) were not used for this study, since it may not be possible to call them 'Soviet Lithuanian historiography'. As the historian Edvardas Gudavičius stated, 'in Stalin's era there was no need for Lithuanian history'. Only the revolutions of Vincas Mickevičius-Kapsukas (1918-1920) and 1940, and a storyline created by Juozas Žiugžda about the friendship between the Lithuanian and Russian nations, had the right to exist. ${ }^{5}$ Moreover, the number

${ }^{5}$ Visa istorija yra gyvenimas. 12 sakytinès istorijos epizodu. Edvarda Gudavičiu kalbina Aurimas Švedas (Vilnius, 2008), p. 230. 
of studies of Lithuanian labour history made a significant jump in the 1960s; therefore, it may be considered a new trend in historical research; this led to the decision to work with historiography written after 1960 as the main source for this study.

Lithuanian history and the history of the Communist Party often grew together into a single body: the history of anything but the Party had to work in favour of the history of the Party. ${ }^{6}$ So the main goal of this study is to deconstruct Soviet Lithuanian studies of workers' history, and find patterns in how the narrative was created in order to write the history of the Lithuanian Communist Party (Lietuvos Komunistu Partija, forthwith - LKP) as a history of the labour movement. This goal is reached by analysing and systematising research on the labour movement and workers done by Soviet Lithuanian historians. The article attempts to take a deeper look at the creation of Soviet Lithuanian historiography, and to explain how the history of Lithuanian workers was used as the groundwork in writing the history of the LKP.

\section{Writing history in Soviet Lithuania}

It is agreed today that Soviet Lithuanian historiography had a lot of shortcomings. First of all, Lithuanian history was often written as a history of socialism or the history of the Lithuanian Communist Party, ${ }^{7}$ whether it was a study of the Grand Duchy of Lithuania in early modern times or a study about Lithuanian land workers in the 19th century under the rule of the Russian Empire. Next, according to the historian Algirdas Jakubčionis, the historical truth was violated (sic) in two ways: either by overestimating certain facts, or completely ignoring others. ${ }^{8}$ The last (but not the least) accusation of Soviet Lithuanian historiography is that historians 'executed the order of the Party'. However, they overdid the quotes from Lenin and Marx in following 'the rules', and therefore ignored the possibilities to follow any scientific method. ${ }^{9}$ That is why, already in 1957, the Lithuanian historian in exile Zenonas Ivinskis stated that

${ }^{6}$ Ibid., p. 202.

${ }^{7}$ A. Jakubčionis, "Baltų dèmių' užpildymas: ko nežinojo išeivijos istoriografija', in: Lietuvos sovietine istoriografija, p. 92.

${ }^{8}$ Ibid.

${ }^{9}$ A. Kasperavičius, '1926 metų perversmas ir tautininkų valdžia sovietinèje istoriografijoje’, ibid., p. 66. 
all Soviet Lithuanian historiography was communist. Later, in 1964, he changed his opinion, and started dividing historiography into two parts: communist historiography, and historiography which endures. ${ }^{10}$ This division became common practice among Lithuanian historians. A. Švedas distinguished four positions on Marxist-Leninist historiography: pessimistic (ignorance), looking for alternatives (finding studies which managed to bypass Marxism-Leninism), optimistic (believing it was possible to use 'real Marxism' for research), and passive (looking at Soviet historiography as an independent tradition of historical research, but avoiding [re] evaluating its methodology). According to him, the dominant positions in Lithuania are pessimistic and passive. ${ }^{11}$

When it comes to Marxism and the methodology of Soviet Lithuanian historiography, the situation is even more complicated. Some may blame Soviet Lithuanian historians for 'Orthodox Marxism'. As George Lukács stated, 'Orthodox Marxism, therefore, does not imply the uncritical acceptance of the results of Marx's investigations. It is not the "belief" in this or that thesis, nor the exegesis of a "sacred" book. On the contrary, orthodoxy refers exclusively to method.' 12 And what could not be found in the work of many Soviet Lithuanian historians was, actually, Marxism itself. Instead of that, according to E. Gudavičius, there was 'Soviet Marxism', that is, "the attachment of "magic words" to empirical research'. ${ }^{13}$ The historian Alfredas Bumblauskas argues that Soviet Lithuanian historians were not Marxist, there was no Marxism in their studies, and most research was done not for scientific purposes, but to legitimise the present by the events of the past,${ }^{14}$ which is not a difficult task, since historians have a 'privileged position of knowledge', and know how the events they are investigating actually turned out. ${ }^{15}$

The first communist organisations (bearing the term 'Communist' in their name) in Lithuania appeared in the spring of 1918,

${ }^{10}$ A. Bumblauskas, 'Konfliktai Lietuvos sovietineje istoriografijoje: psichologija ar metodologija?', ibid., p. 102.

${ }^{11}$ A. Švedas, Matricos nelaisveje, p. 15.

${ }^{12}$ G. Lukács, Marxism and Class Consciousness. Studies in Marxist Dialectics (Cambridge, 1999), p. 1.

13 Visa istorija yra gyvenimas, p. 224.

${ }^{14}$ A. Bumblauskas, 'Konfliktai Lietuvos sovietineje istoriografijoje: psichologija ar metodologija?', p. 92.

${ }^{15}$ H. White, 'History as Fulfillment', in: Philosophy of History after Hayden White, ed. R. Doran (London and New York, 2013), p. 42. 
that is, after the 16 February 1918 declaration of independence. In the autumn of 1918, part of Lithuania was taken over by the Bolsheviks, who declared the Soviet Republic of Lithuania on 16 December 1918. However, the Bolsheviks were defeated at the end of the summer of 1919, and the Communist Party went on to carry out most of its activities underground. ${ }^{16}$ In 1922, the Communist Party participated in the elections to the Parliament (under the name 'Workers' Company' (Darbininku kuopos sąrašas), in which they received five mandates (out of 90). The Parliament was dissolved in 1923, becoming the one and only Lithuanian Parliament before the occupation with communists in it.

The Communist Party of Lithuania was illegal until the summer of 1940, when Red Army troops crossed the borders of Lithuania. To incorporate the new Soviet Republic into the union, it was also necessary to create a 'new course of history'. The Lithuanian philosopher Gintautas Mažeikis, who analyses propaganda, explains that history is one of the most important methods for the formation of the ethnic identity, which is why historical research often becomes a tool to explain and legitimise a new political orientation. ${ }^{17}$ The incorporation of Lithuania into the Soviet Union was justified by historical research. The events in Lithuania from 1918 to 1940 were presented as the teleological course of history: the future of Lithuania was predestined from the moment the Communist Party of Lithuania was founded, and the domestic policy of Lithuania, together with social unrest, led to the communist revolution. In the 1950 s, even the periodisation of Lithuanian history was proposed to be adapted by key changes in productive and social relations, making the October Revolution of 1917 one of the turning points in the history of the Lithuanian Soviet Socialist Republic. ${ }^{18}$ The Russian Revolution did indeed have an influence on the declaration of independence from Russia on 16 February 1918, and it also triggered social changes in Lithuania; nonetheless, the development of Lithuania and the USSR took different and separate paths.

Of course, it is necessary to bear in mind that most Soviet Lithuanian historians who worked on 20th-century Lithuanian history were not free to choose their approach to this topic. The

\footnotetext{
16 S. Yla, Komunizmas Lietuvoje (Vilnius, 2012), pp. 12-14.

17 G. Mažeikis, Propaganda ir simbolinis mastymas (Kaunas, 2010), p. 36.

18 A. Švedas, Matricos nelaisveje, p. 183.
} 
historian Antanas Tyla was quite rigorous, and in 2008 he stated that historical research on 20th-century Lithuania was nothing more than 'destroying science and yourself by creating scientific junk'. ${ }^{19}$ However, Gudavičius recalls that most of the staff in the Faculty of History at Vilnius University were good professionals, but unfortunately they had to remain in the tight box of Soviet ideology. ${ }^{20}$ Tyla also revealed the great deal of control among historians: he was not allowed to work on historical research into the Grand Duchy of Lithuania. Instead, he was asked to work with events of the 1940s. However, with the help of Professor Juozas Jurginis, he managed to avoid this unpleasant task. ${ }^{21}$

Moreover, historians were self-censored, since the boundaries of the 'safe interpretation' of history were never clear. According to Gudavičius, Lithuanian historians who worked in Vilnius were not as free as their colleagues in Moscow and Warsaw, and the 'winds of freedom' in the late 1980s came to Vilnius relatively late. ${ }^{22}$ Until then, both the history and the historical memory were formed intentionally; a lot of historical research was done by the Institute of Communist Party History, which was a branch of the Institute of Marxism-Leninism that existed in the Soviet Union, and this kind of work was used entirely as a propaganda tool. Soviet Lithuanian historians were always under the magnifying glass, and their work had to fulfil requests 'from above'; therefore, some historical events had to be interpreted in a very particular way. ${ }^{23}$ The situation in other Lithuanian historical research institutions was not very different. In 1968, Juozas Žiugžda, the director of the Institute of History, wrote that 'the goal of the institute is to consolidate the socialist system, to cultivate the communist world-view, internationalism and friendship of nations, and to eliminate the leftovers of bourgeois ideology. ${ }^{24}$

According to Mažeikis, by constructing the history and historical memory, every country (including Lithuania as part of the Soviet bloc) could and still can reproduce its loyal citizens. (Constructed) collective memory may help to promote public consensus and

19 'Siekiau būti ištikimas. Antanas Tyla atsako ị Aurimo Švedo klausimus', in: Naujasis židinys-Aidai, nr 1-2 (2008), p. 36.

20 Visa istorija yra gyvenimas, p. 115.

21 'Siekiau būti ištikimas', p. 30.

${ }^{22}$ Visa istorija yra gyvenimas, p. 191.

23 'Siekiau būti ištikimas', p. 31.

${ }^{24}$ A. Gaigalaite, I save ir i istorija pažvelgus (Vilnius, 2002), p. 62. 
hide tension. It can also promote semi-voluntary conformity, and create a new subject, 'a patriot of its propagandist discourse who is ready to expose the mavericks and promote the collective of the new subjects'. ${ }^{25}$ This is a nearly perfect description of some Soviet Lithuanian historians, who were responsible for the institutionalisation of the historical memory, and Lithuanian history itself. The situation of historians who worked in Soviet-occupied Lithuania can be summarised conveniently with a quote from the Soviet Lithuanian historian Aldona Gaigalaite (1927-2015), who confided:

'We were and we still are being blamed for the falsification of history, we were and we still are being called hidebound, Marxists, Stalinists, pseudo-Marxists, schemers, and other names. They will be laughing at us, and quoting our simple-minded writings, and we ourselves do it all the same. And they will be right. ${ }^{26}$

\section{The LKP and the workers, or the LKP as the workers?}

Analysing how the history of the Communist Party of Lithuania was written in Soviet Lithuania is also a rather complicated task. Therefore, this article is an attempt to analyse only a small part of Soviet Lithuanian historiography. Scholarly works of which the main topic was labour and the working-class history of Lithuania were chosen for this study. It was possible to find recurring motifs which helped to create a (more or less) consistent narrative of LKP history in several books.

The earliest studies used for this article were published in 1960. They are the collection of articles Už socialistine Lietuva (For Socialist Lithuania), and the book Darbininku padetis buržuazineje Lietuvoje (The Workers' Situation in Bourgeois Lithuania) by Zigmas Balevičius. The most productive historian in this field was probably Stefa Čepuliene: three books by her on relations between the workers and the LKP came out in 1965, 1978 and 1985. Bronius Vaitkevičius published two books: Socialistine Revoliucija Lietuvoje 1918-1919 m. (The Socialist Revolution in Lithuania 1918-1919) in 1967, and Pirmoji darbininku ir valstiečiu valdžia Lietuvoje (The First Workers' and Peasants' Government in Lithuania) in 1988. Simonas Černiauskas brought out Profsajunginio judejimo vystymasis Lietuvoje 1927-1940 metais (The Development of Labour Unionism

${ }^{25}$ G. Mažeikis, Propaganda ir simbolinis mąstymas, p. 75.

${ }^{26}$ A. Gaigalaitè, I save ir ị istorija pažvelgus, p. 22. 
in Lithuania 1927-1940) in 1966. Bronè Lukoševičienè published Klasiu kovos suküryje (In the Swirl of the Class War) in 1967. The 1965 synthesis of Lithuanian history (Lietuvos TSR istorija, III $t$. (1917-1940)) was also used for this research.

It is important to mention that there were several inconveniences about the LKP and its history. First, the Communist Party of Lithuania was not allowed to exist legally during the interwar period, and could only operate under the cover of organisations in which communists took control. It is also not clear which legal organisations were under the influence of the LKP until 1926, when the Vienybes komitetas (Committee of Unity), an umbrella organisation for communist labour unions) was founded in Kaunas. The party did not have much influence among workers until the economic crisis in the 1930s, and members of the LKP admitted this fact themselves. ${ }^{27}$ Statistics in LKP leaflets show a big jump in 1932, which may indicate the point when the LKP became more active. ${ }^{28}$ Second, Lithuania was not an industrial country; most of its population lived in rural areas and engaged in farming. This did not correspond with the idea of a proletarian revolution, so the LKP did not have a unified vision for workers on the land. That is why Lithuanian political parties and organisations which concentrated on the land question were more successful. Third, in the early years, the LKP (apart from an attempt at a proletarian revolution in 1917-1919) also did not have a clear position regarding the labour movement and labour unions. The leaders of the LKP did not always have similar backgrounds to the workers; for example, some of the party's founders, like Karolis Požèla (1896-1926) and V. Mickevičius-Kapsukas (1880-1935), were born into the families of rich farmers, received a university education abroad, and became professional revolutionaries. So it is unclear what their actual role in labour unions, which were usually apolitical and mostly concerned with economic issues of workers, could have been, and it was sometimes difficult (although attempted) to find their place among the workers as a stratum. That is why Soviet Lithuanian historians had a difficult task: how to create a smooth historical narrative of the LKP as a workers' party?

27 S. Yla, Komunizmas Lietuvoje, pp. 18-19.

28 G. Vaskela, 'Streikai, jų priežastys ir rezultatai Lietuvoje 1929-1939 m. (Remiantis statistinių duomenų analize)', in: Lietuvos istorijos metraštis. 1983 (1984), p. 72. 
The Lithuanian labour movement between 1918 and 1940 was small in comparison to those of industrialised countries. In 1939, there were only about 28,000 industrial workers who worked in factories or workshops with five or more employees in Lithuania, ${ }^{29}$ a country with about 2.15 million residents ( 2.45 million when the Vilnius region was returned to Lithuania by the Soviets on 10 October 1939). Most labour unions were led by the Social Democrats or Christian Democrats, or declared themselves to be apolitical. After the coup in 1926, the Tautininkai (Lithuanian Nationalist Union), the party in power, started to consolidate the labour movement under a loyal organisation called the Lithuanian Workers' Union. Many unions were closed down, and the only alternative for them was to operate as associations of (un)skilled workers, with no reference in their name to the labour movement. In general, it was almost impossible for independent (non-governmental) and grass-roots labour unions to exist after 1936.

Even though it was not very convenient, one way to create a narrative for the history of the LKP was to combine it with the history of the labour movement, and to tell it as if the workers of Lithuania had one main goal, which was a proletarian revolution led by Moscow. Ignoring the early years of the workers' movement in Lithuania (the first known strike occurred in 1861, and the first union was founded in 1892), Zigmas Balevičius wrote that 'the history of unionism in Lithuania shows that Lithuanian workers gained their experience for the class war from earlier times, especially during the Soviet years (1918-19190, when the workers were led by the Communist Party and could protect their rights, create labour unions and fight government policies.' 30

J. Žiugžda, the historian and long-time head of the Institute of History (1948-1970), who was (and still is) infamous for his attitude towards writing Lithuanian history, wrote in 1960 that 'from the first days of its formation, the Lithuanian working class acted in the belief that they should take the same path as the Russian working class, since it would lead them to victory. ${ }^{31}$ However, this approach was

${ }^{29}$ G. Vaskela, Pramonès darbininku skaičius Lietuvoje, Latvijoje ir Estijoje 1935-1939 m. pramonès šakomis, 2002, online: <http://1s1919.esy.es/HTM/lent006. $\mathrm{htm}>$ (accessed 2018-05-07).

${ }^{30}$ Z. Balevičius, Darbininku padètis buržuazineje Lietuvoje (Vilnius, 1960), p. 28.

31 J. Žiugžda, 'Tarybų Rusijos pagalba Lietuvos darbo žmonèms kovoje už tarybų valdžią 1918-1919 metais', in: Už socialistine Lietuva, ed. J. Jurginis, R. Šarmaitis, J. Žiugžda (Vilnius, 1960), p. 29. 
not common in the sparse Soviet Lithuanian historiography of the Stalinist or Khrushchev era. We might speculate that Žiugžda, his work and his influence were responsible for 'merging' the history of the LKP and the history of the Lithuanian labour movement, and making it common practice. But it is also necessary to mention that, according to Tyla, Žiugžda was a 'prisoner' of the LKP Central Committee. Because of his previous political affiliations (between 1918 and 1940, he cooperated with socialist revolutionaries and the Lithuanian Popular Peasants' Union, and was a member of the Lithuanian Social Democratic Party), he always felt threatened by a possible crackdown. That is why he 'lived through Soviet times in fear, and did horrible things, which today we call genocide; if you destroy the historical consciousness, the nation loses its moral basis which encourages people to live and create. This is exactly what Žiugžda was doing. ${ }^{32}$

A new storyline in Lithuanian historiography emerged during the Brezhnev era. The events which took place in the summer of 1940 were explained in this way: the workers' struggle led to a revolutionary situation, proletarian revolution and the introduction of Soviet government. This narrative was quite common; in 1965, the historian Čepuliene prepared teaching material called 'The Lithuanian Workers' Fight for Soviet Government' (1919-1940), in which she wrote:

The lecturer who reads this lecture must show how distressed Lithuanian labouring men were because of the fall of the Soviet government in 1919. They did not want to put up with the bourgeois regime, and, led by the LKP, they fought for the reestablishment of a Soviet government in Lithuania. The long and hard fight by labouring men for the Soviet government was led by the LKP, and ended with the victory of the socialist revolution in $1940 .{ }^{33}$

In the 1920s, Lithuanian workers' organisations and labour unions usually tended to engage only in the fight for better wages and workplace conditions, and for social security, and tried to leave politics out. However, Soviet historiography put the emphasis on the political affiliations and the activism of unions, which raises some doubt about whether workers' organisations were portrayed correctly. In 1966, Simonas Černiauskas promoted a similar image

32 'Siekiau būti ištikimas', p. 35.

33 S. Čepulienè, Lietuvos darbo žmonių kova už tarybų valdžia (1919-1940) (Vilnius, 1965). 
of Lithuanian labour unions as the main force in the fight for Soviet government. In his publication on the workers' movement in Lithuania (1927-1940), he wrote:

Labour unionism in Lithuania was part of the workers' movement, and it had a long and complicated history. This movement is important for our labouring men's life; if we study it, we can understand better the role of labour unions and workers' organisations in the revolutionary fight. It also helps to educate labouring men in the communist way, to raise their consciousness, and to promote communist relationships. ${ }^{34}$

He also proposed that in June 1940, the 'fascist dictatorship' 35 was abolished in Lithuania. According to Černiauskas, 'forward' and revolutionary labour unions played a major role in this change: 'Revolutionary workers' unions, part of the Lithuanian proletariat, helped the LKP to organise and unite the working class to attain the final goal, the abolition of the capitalist system.' ${ }^{36}$ So, as we see, such arguments would mean that the workers themselves were responsible not only for the abolition of Antanas Smetona's regime, but also for the implementation of Soviet rule in Lithuania. However, as we already know, the workers who harboured these goals were not acting independently, and their actions were controlled or inspired by the LKP, which was working among the labour unions. Furthermore, the Molotov-Ribbentrop Pact and its secret supplementary protocols dividing Europe (and Lithuania) into 'spheres of interest' tell us about the interests of the USSR and the Communist Party of the Soviet Union (CPSU) before 1940. Since the LKP worked under the influence of the CPSU, the 'proletarian revolution' and 'abolition of the capitalist system' did not come from below, but from above. That is why it is clear that Lithuanian workers (as a stratum) were not responsible for the changes in the political, social and economic system in June 1940.

Creating such a historical narrative in which 'the communists and/or the members of the LKP' are replaced by 'the workers' helped to promote an image of voluntary change in the government of Lithuania, and voluntary admission to the USSR. So it is a good

34 S. Černiauskas, Profsajunginio judejimo vystymasis Lietuvoje 1927-1940 metais (Vilnius, 1966), p. 3.

35 'Fascist dictatorship' is a common expression in Soviet Lithuanian historiography describing the authoritarian rule of President Antanas Smetona (1926-1940).

36 S. Černiauskas, Profsajunginio judejimo vystymasis Lietuvoje 1927-1940 metais, p. 59. 
example of how history is used for ideology. According to Mažeikis, we can simplify political narratives to narrow down the variety of political philosophy to a level of easy perception, in order to give a meaning to the ideology. The ideologists who were doing this job were not concerned with the mass consciousness or the construction of the subject, but with the protection and promotion of 'the great narrative', and supervising or repressing revisionism and external criticism. ${ }^{37}$

From the mid-1960s, Lithuanian workers and their (questionable) support for the Communist Party before 1940, were brought into the historical narrative of the Communist Party of Lithuania. Moreover, the boundaries between 'the workers' and 'the Party' began to vanish, and both terms were used as synonyms. For example, in his book Pirmoji darbininku ir valstiečiu valdžia Lietuvoje, B. Vaitkevičius wrote that in 1918 'the labour unions of Vilnius became more active [...] The workers expected that the [German] occupation would be over, and the Soviet government would gain power.' ${ }^{38}$ According to the author, the working class was the main executor of the changes in power and the government. ${ }^{39}$ Another brochure written by Čepulienè in 1978 used the same motif. She wrote that 'as an outcome of the selfless revolutionary struggle of labouring men, on 16 December 1918, Soviet authority was declared in Lithuania, ${ }^{40}$ and it was the labour unions led by communists that were the most important factor in the socialist remaking of the economy and introducing the means of Soviet government in the region. ${ }^{41}$

So, as we can see, in these cases, the factual truth was concealed by the traditional system of rewriting history, ${ }^{42}$ which was done by denying or ignoring certain facts. However, according to Hannah Arendt, by telling the same lie so many times, it is possible to start actually believing in it. The better the liar is, the more likely s/he will become a victim of his/her own lies, and the fool who falls for his lies is much more likely to be perceived as a trustworthy person

${ }^{37}$ G. Mažeikis, Isikitiniamai. Sąmoningumo metamorfozès (Kaunas, 2013), p. 278.

${ }^{38}$ B. Vaitkevičius, Pirmoji darbininku ir valstiečių valdžia Lietuvoje (Vilnius, 1988), p. 25.

39 Ibid., p. 155.

${ }^{40}$ S. Čepulienè, Kovoje ir darbe. Tarybu Lietuvos profsajungu nueitas kelias (Vilnius, 1978), p. 7.

${ }^{41}$ Ibid., p. 9.

${ }^{42}$ H. Arendt, Tarp praeities ir ateities (Vilnius, 1995), p. 255. 
than a cold-blooded liar who stands aside from his lies. ${ }^{43}$ Today, we can only guess whether this may be the reason for a repetitive historical narrative about voluntary workers' revolution, and whether there was anybody to believe in it, either Soviet Lithuanian historians, members of the Party, or ordinary Soviet citizens.

\section{The LKP, the leader of the workers?}

Another approach to the relationship between the workers and the Communist Party was that, in general, the leader of the workers was the LKP, and other political parties or organisations played a minor role in the labour movement. Sometimes, the influence of the LKP on workers was explained in the most unusual ways. For instance, in 1967, Lukoševičiené published an article about a workers' club in Kaunas, where she stated that one of the Lithuanian communist leaders, the professional revolutionary Karolis Požèla, 'became the soul of the workers' club even though he had never been there.' ${ }^{44}$ In his book on propaganda, Mažeikis compared J.R.R. Tolkien's imaginary elves and their Medieval world to the history created by imaginary Soviet heroes, which was retold, biased and ideologised by Soviet historians of the Party. The only difference is that Tolkien's fans do not have any political and/or repressive power, but Soviet heroes did, and tried to change or reject the facts. ${ }^{45}$ Could Požèla be one such hero, who had a whole world built around him, or could he actually inspire people and public spaces without meeting and visiting them? Unfortunately, that is a question nobody can answer.

Lithuanian scholars of propaganda analysis and historians of historiography agree on the fact that Soviet propaganda presented itself as the science of Marxism-Leninism, but also carried out the politics of oblivion. In the Soviet lexicon, 'science' meant Marxist-Leninist philosophy, its dialectical and historical materialism, and the history of the Communist Party of the Soviet Union. ${ }^{46}$ Nevertheless, Švedas argues that it is important to draw a line between history as a science and history as an area of propaganda. ${ }^{47}$ Sometimes, this line

${ }^{43}$ Ibid., pp. 280-281.

${ }^{44}$ B. Lukoševičienè, Klasiu kovos sūkuryje (Apie Kauno profsajungų darbininku klubo veikla 1919-1921 m.) (Vilnius, 1967), p. 4.

${ }^{45}$ G. Mažeikis, Propaganda ir simbolinis mastymas, pp. 114-115.

${ }^{46}$ Ibid., p. 241.

47 A. Švedas, Matricos nelaisvejje, p. 33. 
has to be drawn not between two or more different books of Soviet Lithuanian historical studies, but within one. This can be seen in Soviet Lithuanian labour history studies: usually Soviet Lithuanian historians tried to 'find the balance' between the narrated and the actual role of the LKP in the labour movement. It can also be seen in the history synthesis of the Lithuanian Soviet Socialist Republic (between 1917 and 1940) edited by Gaigalaitè, Šarmaitis and Žiugžda and published in 1965. It writes: 'The Lithuanian working class, which was led by the Communist Party, always fought for better workers' living conditions, higher wages, shorter working hours, and better workplace conditions. ${ }^{48}$ Even though there is plenty of data showing that the workers organised themselves, and the labour unions fought for better workplace conditions, there is none showing that the LKP was the only leader of the Lithuanian labour movement. If there was an actual case, Soviet Lithuanian historiography would have had stronger evidence to support the claims about the great LKP involvement in workers' issues. As Tyla believed, historical synthesis was the kind of work which best revealed the irrationality of Soviet Lithuanian historiography, since the most important part of these books were ideological postulates, instead of consideration based on data. ${ }^{49}$

The previous historiographical statement about the Lithuanian working class being led by the LKP became something close to a template for the later books, and the approach to the labour movement in Lithuania until 1940, when 'the working class led by the LKP rose up for the brave new struggles for workers' social liberation and the freedom of Lithuania.' ${ }^{50}$ In 1966, Černiauskas stated that 'the LKP was fighting for the working class and the unity of the labour unions, it helped to organise the fight for everyday needs, justice and freedom. That is why workers' unions were close to the LKP and supported the Party. ${ }^{51}$ Most of his claims were based on Kapsukas' writings published after 1945. V. Mickevičius-Kapsukas was one of the founders and leaders of the LKP, so this source covered only one side of the story. Both in Kapsukas' writings

${ }^{48}$ Lietuvos TSR istorija, III tomas: Nuo 1917 iki 1940 m., ed. A. Gaigalaitè, R. Šarmaitis, J. Žiugžda (Vilnius, 1965), p. 138.

49 'Siekiau būti ištikimas', p. 36.

${ }^{50}$ Lietuvos TSR istorija, p. 258.

51 S. Černiauskas, Profsajunginio judejjimo vystymasis Lietuvoje 1927-1940 metais, p. 4. 
and in Černiauskas' brochure, the role of the LKP in the labour movement seems to be exaggerated, and the unions were presented only as a tool of the LKP: 'Labour unions were implementing the politics of the LKP, defending the interests of the working class. In 1930-1931, most unions in Kaunas were under the influence of the communists. ${ }^{52}$ Cerniauskas stated that "constant attention and care of the LKP were the main factor for the future development of labour unions. The number of unions rose, and members gained their [communist] ideology. ${ }^{53}$

Čepulienè made similar claims about the leadership of the LKP in 1978. According to her, "the Lithuanian Communist Party was the only political party which was able not only to keep the labour unions together during fascist times, but even managed to reorganise them into the revolutionary avant-garde, the proletariat. ${ }^{54}$ Čepuliene also stated that 'in the times of Antanas Smetona's regime (1927 to 1940), the LKP became a recognised leader of the whole working class. It managed to create a political revolutionary army: most workers followed the Communist Party. ${ }^{55}$ It is not clear how many members or sympathisers of the LKP were involved in the Lithuanian labour movement, but some numbers may help to give an idea and raise questions about the actual influence of the LKP. For example, in 1923, the Darbo federacija (Labour Federation, a Catholic labour union) had 20,000 members, in 1940 its successor the Lietuvos krikščioniu darbininku sajunga (Lithuanian Christian Workers Union) had 8,000 members. ${ }^{56}$ In 1930, the LKP had 650 members, and it grew to be a party of 1,741 members before the occupation in 1940. The historian Jonas Švilpa, who investigated the underground activities of the LKP in the 1930s, believes that the LKP was too small and unprepared to be a serious political party, and should be considered more a political group. ${ }^{57}$

52 Ibid., p. 21.

${ }^{53}$ Ibid., p. 16.

54 S. Čepulienè, Kovoje ir darbe. Tarybu Lietuvos profsajungu nueitas kelias, p. 30 .

${ }^{55}$ Ibid., p. 31.

56 A. Svarauskas, 'Lietuvos darbo federacijos nesutarimai su katalikų politine srove po 1926 m. perversmo’, in: Lietuviu kataliku mokslo akademijos metraštis, t. 31 (2008), p. 74.

57 J. Švilpa, Kominternas ir komunistinis pogrindis Lietuvoje XX a. 4-ajame dešimtmetyje (organizaciniai veiklos aspektai), PhD dissertation (2007), pp. 131, 134. 
Although it is doubtful whether the LKP was the only (or an actual) leader of the labour movement, this approach by Soviet Lithuanian historians, however, allowed them to broaden the history of the labour movement in Lithuania, and introduce new narratives alongside those imposed by the era. In 1988, Vaitkevičius wrote about the LKP as the leader of the labour movement, but he also included other 'minor political powers' involved in workers' issues. According to Vaitkevičius, in the summer of 1918 there were ten labour unions with 5,000 members in Vilnius. The unions were organised by region, nationality or even religion (Jewish and Catholic unions). ${ }^{58}$ According to him, this happened because of the unique historical context in Lithuania. He would probably have been accused of 'nationalism' for this view a couple of decades earlier.

Tyla claimed that Soviet Lithuanian historians not only had to reveal and analyse historical processes, but also to preserve discipline and protect themselves from Soviet indoctrination. ${ }^{59}$ For instance, Vaitkevičius managed to provide new and valuable data on Lithuanian labour history, but he still had to come to the 'required' conclusions. Vaitkevičius wrote that this decomposition of labour unions was criticised by the communists alongside 'opportunist' and 'neutral' unions, since the unions had to fight in order to achieve the socialist revolution: 'Labour unions must be related to communist organisations and recognise them as their leader. Only the communist leadership can help the unions to succeed. ${ }^{\prime 60}$ The leadership of the LKP was explained by the First Congress of the LKP (starting on 15 September 1918), which gave 'a Marxist-Leninist basis and gave internationalist proletarian principles to the Lithuanian labour movement. ${ }^{91}$ This statement provided the LKP with the same generalised role of leader and main organiser of the workers. Nevertheless, it is possible to follow the proposal of Švedas, try to 'filter out' or 'read between the lines', and see the empirical value of the facts about non-communist unions provided by Vaitkevičius.

${ }^{58}$ B. Vaitkevičius, Pirmoji darbininku ir valstiečiu valdžia Lietuvoje, p. 59.

59 'Siekiau būti ištikimas', p. 37.

${ }^{60}$ B. Vaitkevičius, Pirmoji darbininku ir valstiečiu valdžia Lietuvoje, p. 60.

${ }^{61}$ Ibid., p. 36. 


\section{The LKP, the (in)fallible party?}

It was sometimes extremely difficult to find how to reconcile the history of the labour movement and the history of the LKP, and the workers' history itself, and to meet the ideological requirements, that is, the application of a Marxist-Leninist approach to research, and to provide an explanation and/or justification of the events in June 1940. A. Švedas compared the fictionality of Soviet Lithuanian historiography and the situation of historians with the film Matrix in his book Matricos nelaisveje (The Captivity of the Matrix). However, another sci-fi comparison can be made as well, and Soviet Lithuanian historiography can be presented as Star Trek's holodeck. ${ }^{62}$ The main difference between the Matrix and the holodeck is awareness. People are not aware of being in the Matrix, while one can visit a holodeck with the conscious mind, by choice and being aware of where one is. As in the Matrix, things look and feel real in a holodeck, but instead of a pill which has the power of giving awareness, a holodeck may malfunction, and you can see glitches uncovering its original grid and showing its (un) reality. These 'glitches' recur as a trope of the mistakes of the LKP in Soviet Lithuanian historiography regarding the labour movement. Sometimes the failures of the LKP and its tactics were recognised, and sometimes they were denied and/or vindicated in rather bizarre ways, exposing the fictionality of some narratives of labour history created in Soviet Lithuanian historiography.

Lithuania's case was different to industrialised countries, for most people were farm labourers in rural areas. Before the II World War, only about 8 per cent of people were employed in industry, while 80 per cent worked in agriculture. ${ }^{63}$ That is why the common narrative of (industrial) workers' revolution as a reason for the LKP gaining power in the country was harder for Soviet Lithuanian historians to accept. Moreover, the rather negative attitude of the newly founded LKP towards land workers made the creation of a 'suitable narrative' even more difficult. So when it comes to the failed attempts of LKP actions in the labour movement, it is possible to find a mea

${ }^{62}$ A holodeck is fictional technology which creates realistic environments and landscapes; a participant in a holographic simulation is not able to distinguish a real object from a simulated one.

${ }^{63}$ M. Drèmaite, Progreso meteoras. Modernizacija ir pramonès architektūra Lietuvoje 1918-1940 m. (Vilnius, 2016), p. 11. 
culpa expressed in the pages of Soviet Lithuanian historiography. Some Soviet Lithuanian historians admitted that the LKP had made mistakes in its tactics, and other historians tried to justify these mistakes, or even made creative deductions denying failures, which were not compatible with the proven facts.

Černiauskas was probably the first to write about the tactical mistakes of the LKP on behalf of the labour movement in 1966, but his writings received harsh criticism from other scholars. The problem was his approach, and his claims that 'at the beginning, the illegal leftist [communist] labour unions were weak strike leaders. They were not ready to lead workers' economic battles, they did not know how to stand up as leaders, and could not fight the attack of capital. ${ }^{64}$ Moreover, Černiauskas argued that 'in general, unionism in Lithuania in 1935-1940 did not become a mass movement. Even though the economic workers' struggle was getting bigger and stronger, and the workers were becoming more revolutionary, the labour unions did not grow. Illegal unions were usually small, and operated only inside one factory or company. They were not united, and acted independently of each other. ${ }^{65}$ These propositions do not go along with the official history of the LKP as the leader of the labour unions and the workers themselves; it also clashes with the explanation that the declaration of Soviet government in the summer of 1940 was the outcome of a strong revolutionary workers' movement.

In 1978, Čepulienè wrote that illegal (communist) unions on the periphery were not cooperating with each other, their activities were rare, and only a small number of workers were members of labour unions. However, this was followed by a contradictory statement that the unions had a big influence on most workers. ${ }^{66}$ In another book, Čepulienè wrote that

'the communists who worked with the agricultural workers and their unions did not pay enough attention to organising the batraks [landless seasonal agricultural workers for hire, originally buožiu samdiniai] [...] They were not politically conscious. Later, the revolutionary labour unions corrected this sectarian error. ${ }^{67}$

${ }^{64}$ S. Černiauskas, Profsajunginio judejjimo vystymasis Lietuvoje 1927-1940 metais, p. 26.

${ }^{65}$ Ibid., p. 49.

66 S. Čepulienè, Kovoje ir darbe, p. 27.

$67 \mathrm{~S}$. Čepulienè, Už kovingas profsajungas. LKP vaidmuo organizuojant profsajungini judèjima buržuazineje Lietuvoje (1919 m. antroji pusè - 1940.06.15) (Vilnius, 1981), p. 29. 
She also admitted that the LKP 'did not have principles for working inside the unions at that time. Communist factions in the unions were composed only of members of the Communist Party itself.' ${ }^{68}$ Čepuliene justified failures, explaining that 'the LKP was learning to work with the masses, and it did not always choose the right tactic, ${ }^{, 69}$ and that 'the LKP was a young and inexperienced party, it did not know how to combine legal and illegal activities, and underestimated the need for economic struggle. At that time, the parties did not immediately understand that the conditions had changed, so they made mistakes and grew further apart from the masses. ${ }^{70}$ What is more, Čepuliene stated that

'some communists perceived the labour unions as political workers' organisations. Others believed it was not worth leading the economic struggle, since the bourgeois government would not improve workers' conditions anyway, so it is necessary to fight the political battle only, and try to reintroduce Soviet government. Other communists thought that the economic struggle was unnecessary, since it was only a distraction, and distracted workers from the main goal, the fight for Soviet government. ${ }^{71}$

Even though the failure of the LKP to choose a proper strategy was admitted as a tactical error, in the same book Čepuliene also proposed that 'the LKP managed to rule the roost in the union movement; in general, it chose the correct way to fight, in order to fulfil the economic, social and political goals of the workers, and related their activities to the revolutionary movement. ${ }^{72}$ These quotes show that Soviet Lithuanian historiography had a hard task to create a smooth storyline about the role of the LKP in the labour movement, and in order to do so, a lot of compromises had to be made: sometimes, history as a science had to give way to ideology. One can only imagine today the cognitive dissonance experienced by Soviet Lithuanian historians who had to come up with the creation of such narratives.

It is also worth noting that the 'mistakes of youth' and 'looking for the right path' are other popular tropes in Soviet historiography, and were common in the (auto)biographies of communists with an 'unclear past', as a way of explaining previous political affiliations.

\footnotetext{
68 Ibid., p. 30.

${ }^{69}$ Ibid., p. 52.

${ }^{70}$ Ibid., pp. 60-61.

${ }^{71}$ Ibid., p. 38.

72 Ibid., p. 42.
} 
Finding 'the right path' reduced the mistakes of a person's past, as the events of June 1940 reduced the mistakes of the LKP's work within the labour movement. This can be seen particularly in the biographies of former socialist revolutionaries written during the Soviet years. In the short biography of the poet Kazys Jakubenas (1908-1950), who was most likely an anarchist, even though he had not declared his world-view at his time, written in 1958, the author and literary scholar Vytautas Galinis stated that Jakubenas 'did not manage to find a proper path of revolutionary fight $[. .$. his poems were full of spontaneous rebellion and an anarchistic and individualist mood'. ${ }^{73}$ Similar descriptions were used for other authors and artists who kept their non-communist or anti-communist political beliefs after 1940, but this is an entirely different topic which requires a separate study.

\section{Conclusions}

Even though a lot of historical studies on the history of the Grand Duchy of Lithuania conducted from 1945 to 1990 are recognised for their empirical value, we cannot say the same about studies of 20th-century Lithuania written by Soviet Lithuanian historians. A lot of books and articles written about issues such as the labour movement and the LKP are rejected nowadays as a product of ideology. It is not possible to deny that such is the nature of Soviet Lithuanian historiography, but we can argue that all the 'official histories' should be properly reviewed.

As this article has revealed, until 1988, Lithuanian labour history was tied to the history of the Lithuanian Communist Party. It is still hard to draw a line between these two topics, since most works by Soviet Lithuanian historians treated the workers involved in the labour movement as communists (members or sympathisers of the LKP), emphasised or hyperbolised the involvement and leadership of the LKP in the labour movement, and invented the leaders of the movement, while keeping the other parties involved out of the history books of the time.

Historians of the younger generation, like A. Švedas, have made a great breakthrough by analysing the community of historians in Soviet Lithuania and courses of history writing, but a critical review

73 V. Galinis. 'Vargo ir kovos dainius', in: Kazys Jakubėnas. Raštai, III t. (Vilnius, 2009), p. 247. 
of the Soviet Lithuanian historiography of Lithuania and the LKP between 1918 and 1940 has never been undertaken, and a new history of the LKP has not yet been written, therefore leaving a lot of unanswered questions about the history of the labour movement in Lithuania. This is why these topics are still more or less a mystery, to both professional historians and Lithuanian society, which has uncomfortable feelings towards the labour movement and the workers as the enemy of the Lithuanian state. The dominant narrative in Lithuanian labour history is still the one imposed by Soviet Lithuanian historiography, so 'the spectre of communism is haunting' the history of the labour movement and today's labour movement itself. ${ }^{74}$ Only a revision of Soviet Lithuanian historiography and more new research into these topics can sort out the past, present and future.

\section{Author Details}

Ugnè Marija Andrijauskaite is a researcher and lecturer currently working at Vytautas Magnus University in Kaunas. She has a PhD in history. Her main field of research is the social and cultural history of Lithuania in the 20th century.

Address: Vytautas Magnus University, Faculty of Humanities, Department of History, V. Putvinskio St. 23-407, LT-44243 Kaunas, Lithuania.

E-mail: ugnemarija.a@gmail.com

\section{Bibliography}

ARENDT, Hannah. Tarp praeities ir ateities (Vilnius, 1995).

BALEVIČIUS, Zigmas. Darbininku padètis buržuazinèje Lietuvoje (Vilnius, 1960).

ČEPULIENĖ, Stefa. Kovoje ir darbe. Tarybu Lietuvos profsajungu nueitas kelias (Vilnius, 1978).

ČEPULIENĖ, Stefa. Lietuvos darbo žmoniu kova už tarybų valdžia (1919-1940) (Vilnius, 1965).

ČEPULIENĖ, Stefa. Už kovingas profsajungas. LKP vaidmuo organizuojant profsajungini judèjima buržuazinejje Lietuvoje (1919 m. antroji pusé - 1940.06.15) (Vilnius, 1981).

ČERNIAUSKAS, Simonas. Profsajunginio judejiimo vystymasis Lietuvoje 1927-1940 metais (Vilnius, 1966).

${ }^{74}$ In February 2016, the prime minister of Lithuania Algirdas Butkevičius stated that the teachers who went on strike were acting under the influence of Russia. Read more, online: <http://www.bns.lt/topic/1911/news/49091847/> (accessed 2018-05-07). 
DRĖMAITÉ, Marija. Progreso meteoras. Modernizacija ir pramonés architektūra Lietuvoje 1918-1940 m. (Vilnius, 2016).

GAIGALAITE, Aldona. I save ir $i$ istorija pažvelgus (Vilnius, 2002).

HOBSBAWM, Eric. How to Change the World. Reflections on Marx and Marxism (London, 2011).

YLA, Stasys. Komunizmas Lietuvoje (Vilnius, 2012).

GALINIS, Vytautas. 'Vargo ir kovos dainius', in: Kazys Jakubėnas. Raštai. III tomas (Vilnius, 2009), pp. 242-249.

Lietuvos sovietine istoriografija, eds. A. Bumblauskas, N. Šepetys (Vilnius, 1999).

Lietuvos TSR istorija, III tomas (nuo 1917 iki 1940 m.), eds. A. Gaigalaite, R. Šarmaitis, J. Žiugžda (Vilnius, 1965).

LUKÁCS, George. Marxism and Class Consciousness. Studies in Marxist Dialectics (Cambridge, 1999).

LUKOŠEVIČIENĖ, Bronè. Klasių kovos sūkuryje. (Apie Kauno profsajungu darbininku klubo veikla 1919-1921 m.) (Vilnius, 1967).

MAŽEIKIS, Gintautas. Isikitinimai. Samoningumo metamorfozès (Kaunas, 2013).

MAŽEIKIS, Gintautas. Propaganda ir simbolinis mastymas (Kaunas, 2010).

'Siekiau būti ištikimas. Antanas Tyla atsako ị Aurimo Švedo klausimus', in: Naujasis židinys-Aidai, nr. 1-2 (Vilnius, 2008), pp. 30-37.

Philosophy of History after Hayden White, ed. R. Doran (London, New York, 2013).

SVARAUSKAS, Artūras. 'Lietuvos darbo federacijos nesutarimai su katalikų politine srove po 1926 m. perversmo', in: Lietuviu kataliku mokslo akademijos metraštis, nr. 31 (Vilnius, 2008), pp. 49-76.

ŠVEDAS, Aurimas. Matricos nelaisveje: sovietmečio lietuviu istoriogafija (1944-1985 m.) (Vilnius, 2009).

ŠVILPA, Jonas. Kominternas ir komunistinis pogrindis Lietuvoje XX a. 4-ajame dešimtmetyje (organizaciniai veiklos aspektai). Doctoral dissertation (Vytautas Magnus University, 2007).

Už socialistinę Lietuvą, eds. J. Jurginis; R. Šarmaitis; J. Žiugžda (Vilnius, 1960).

VAITKEVIČIUS, Bronius. Pirmoji darbininku ir valstiečiu valdžia Lietuvoje (Vilnius, 1988).

VASKELA, Gediminas. Pramonès darbininku skaičius Lietuvoje, Latvijoje ir Estijoje 1935-1939 m. pramonès šakomis (Vilnius, 2002).

VASKELA, Gediminas. 'Streikai, jų priežastys ir rezultatai Lietuvoje 1929-1939 m. (Remiantis statistinių duomenų analize)', in: Lietuvos istorijos metraštis. 1983 (1984), pp. 63-77.

Visa istorija yra gyvenimas. 12 sakytines istorijos epizodu. Edvarda Gudavičiu kalbina Aurimas Švedas (Vilnius, 2008). 


\title{
LIETUVOS KOMUNISTŲ PARTIJA KAIP DARBO JUDE்JIMAS. SOVIETINĖS ISTORIOGRAFIJOS NARATYVAI
}

Santrauka

\author{
UGNE MARIJA ANDRIJAUSKAITE்
}

Šiame straipsnyje pristatoma ir analizuojama, kaip Lietuvos Komunistų Partijos istorijos rašymas 1960-1988 m. siejosi su Lietuvos darbininkų ir organizuoto darbo judejjimo istorijos rašymu. Pastebima, jog daugelis tiriamuoju laikotarpiu sovietinejje Lietuvoje parašytų mokslinių publikacijų ir monografijų ieškojo LKP ir darbo judèjimo istorijos ryšių, nagrinejjo komunistų partijos įtaką darbininkijai ir profesinèms sajungomis. Šiuose tyrimuose profesinès sajungos ir jų veikla pristatytos kaip dirbusios daugiausiai Maskvos labui bei padejjusios išauginti LKP ịtaką tarp Lietuvos piliečių ir lèmusios 1940-ujų birželio mèn. įvykius.

Dažnai šiuose tyrimuose matoma tendencija terminus darbininkai, darbo žmonès ir LKP nariai vartoti kaip sinonimus, taip sudarant ịspūdį, jog darbo judejjimas buvo susijęs tik su LKP. Todèl sovietineje Lietuvos istoriografijoje ịsitvirtino LKP kaip pagrindinès darbininkų lyderès 1918-1940 m. Lietuvoje statusas. Tačiau drauge tai lèmé tokių tyrimų kaip ideologinès produkcijos atmetimą, nepaisant juose esančių vertingų empirinių faktų, leidžiančių geriau pažinti tarpukario Lietuvos darbininkiją, organizuotą darbo judèjimą bei jame vykusias politines ir ideologines kovas.

Analizuojant sovietinę Lietuvos darbininkijos istorijai skirtą istoriografiją buvo pastebèta, jog kartais, susidūrus su sunkumais kuriant sklandų, nuoseklų pasakojimą apie LKP kaip darbininkišką partiją ir/ar darbo judèjimo lyderę, pažymètos LKP taktinès klaidos bei nesėkmès mėginant vadovauti profesinèms sajungoms. Tokiu būdu šiuos tyrimus skaitantys istorikai ir kiti besidomintys galejo ir gali kelti klausimus apie šiai temai skirtos sovietinès istoriografijos (ne)patikimumą.

Straipsnyje daroma prielaida, jog sovietinei istoriografijai Lietuvos darbo ir darbininkijos istoriją susiejus tik su LKP, net ir šiandien darbo judejjimas tarpukario Lietuvoje vis dar laikomas nesavarankišku ir priklausiusiu nuo minètos partijos. Todèl pažymima, jog norint toliau plètoti darbo istorijos tyrimus bei geriau suvokti $\mathrm{XX}$ a. ir modernaus darbo judejjimo Lietuvoje specifiką, reikia atlikti išsamią sovietinès istoriografijos reviziją. 